\title{
Effect of temperature and salinity on the toxicity of chromium to three estuarine invertebrates (Corophium volutator, Macoma balthica, Nereis diversicolor)
}

\author{
V. Bryant, D. S. McLusky, K. Roddie and D. M. Newbery \\ Department of Biological Science, The University, Stirling FK9 4LA, Scotland
}

\begin{abstract}
Acute toxicity of hexavalent chromium to 3 estuarine animals (Corophium volutator, Macoma balthica, Nereis diversicolor) has been studied at 3 temperatures $\left(5,10,15^{\circ} \mathrm{C}\right)$ and a range of salinities ( 5 to $40 \%$, in $5 \%$ increments), at time intervals of up to $384 \mathrm{~h}$. Toxicity increased as temperature increased and as salinity decreased. From an analysis of variance, the significant factors and their interactions were included in a response surface model for $C$. volutator and $M$. balthica separately. The range of toxicity values for a single species under a variety of environmental conditions exceeded the previously reported range of toxicity values for several species maintained in constant conditions. It is emphasized that due account should therefore be made of environmental conditions when evaluating the toxicity of chromium, in the estuarine environment.
\end{abstract}

\section{INTRODUCTION}

The limited data available on the acute toxicity of chromium to vertebrates and invertebrates in both marine and fresh-water environments have been summarized by Taylor (1981) and Mance et al. (1984). However, data on the effects of variations in salinity and temperature, which are comparable to those encountered in estuaries, in relation to chromium toxicity are not available for animals. Where such studies have been conducted with other metals (Theede, 1980; Coglianese, 1982; Cotter et al., 1982; Denton and Burdon-Jones, 1982), they have generally shown that the acute toxicity of heavy metals increases as temperature increases and as salinity decreases. Frey et al. (1983) have reported that hexavalent chromium is very inhibitory to the growth of estuarine phytoplankton in fresh-water, but less inhibitory as salinity increases. Many industrial effluents containing chromium are discharged into estuaries, but predictions of their possible effects based on the results of marine or freshwater studies, rather than estuarine studies, may be inappropriate. In the study reported here the effects of temperature and salinity on chromium toxicity were investigated using species representing taxonomic diversity as well as ecological importance within the estuarine ecosystem. The following species were chosen: the amphipod crustacean Corophium volutator (Pallas); the bivalve mollusc Macoma balthica (L.) and the polychaete annelid Nereis diversicolor (O. F. Müller).

\section{MATERIALS AND METHODS}

Animals were collected throughout the year from the Tay estuary, Eastern Scotland, with Macoma balthica and Corophium volutator from Tayport, and Nereis diversicolor from Balmerino. Tayport and Balmerino experience a salinity range, at low tide, of 11 to $32 \%$ and 0.2 to $20.6 \%$ respectively, with both having an annual temperature range of 3 to $16{ }^{\circ} \mathrm{C}$ (Khayrallah and Jones, 1975). Experiments were conducted in a constant temperature room at 5,10 or $15^{\circ} \mathrm{C}\left( \pm 0.05 \mathrm{C}^{\circ}\right)$. A regime of $12 \mathrm{~h}$ light, $12 \mathrm{~h}$ darkness was maintained,

The acute toxicity of hexavalent chromium (as potassium dichromate) was determined under static conditions following SCA protocol (Anonymous, 1980). Stock solutions of analar grade $\mathrm{K}_{2} \mathrm{Cr}_{2} \mathrm{O}_{7}$ were prepared in water of the appropriate salinity and test solutions obtained by dilution. Chromium levels were checked 
colorimetrically using S-diphenylcarbazide and sulphuric acid (J. Riley, pers. comm.). Measured concentrations closely approximated to nominal values and there was no appreciable loss of metal from solution during experimentation.

Salinities of 5 to $30 \%$ were prepared by dilution of natural sea-water with deionized water. Salinities of 35 and $40 \%$ were prepared by the addition of Gerard's sea salt to natural sea-water. The sea-water was passed through polystyrene filters to remove suspended solids before storage in sea-water tanks.

Experiments for Corophium volutator and Nereis diversicolor each had a $3 \times 7 \times 8$ factorial design with temperatures of $5,10,15^{\circ} \mathrm{C}$, chromium concentrations of $2,4,8,16,32,64$ and $128 \mathrm{ppm}$ (+ controls) and salinities of $5,10,15,20,25,30,35$ and $40 \%$. The experiment for Macoma balthica was a $3 \times 7 \times 6$ factorial design with the same temperatures and chromium concentrations as above and salinities of 15 to $40 \%$ in $5 \%$ increments. $M$. balthica is unable to survive for periods of longer than $24 \mathrm{~h}$ in salinities below $15 \%$. Animals were fully acclimated to each salinity and temperature for $5 \mathrm{~d}$ before use. Temperature acclimation was accomplished by conducting experiments at the appropriate season (e.g. $5{ }^{\circ} \mathrm{C}$ experiments in winter). Oxygen concentration, $\mathrm{pH}$, temperature, salinity, and chromium concentrations were monitored regularly. Twenty $M$. balthica and $C$. volutator, and $10 \mathrm{~N}$. diversicolor were used for each temperature, salinity and chromium combination. Sterile sand was provided as substrate in all test vessels and no food was provided throughout the experiment. Vessels were examined, dead animals removed and test solutions changed daily for $384 \mathrm{~h}$. Death was noted as gaping in $M$. balthica, and lack of muscular or pleopod activity in $N$. diversicolor and $C$. volutator.

At each time interval the cumulative \% mortality was calculated following the method of Lloyd (1979). This value (expressed as probits) was plotted as a function of time (expressed logarithmically) directly onto logarithmic-probability graph paper for each of the concentrations of chromium used. A straight line was fitted by eye to each set of data, giving greater weight to those values between 25 and $75 \%$ response. The time for $50 \%$ mortality, the median period of survival $\left(\mathrm{LT}_{50}\right)$, was then read from the graph. Concentration response curves were plotted on double log paper using the $\mathrm{LT}_{50}$ values calculated for each

Table 1. Corophium volutator. Median periods of survival in hours $\left(\mathrm{LT}_{50}\right)$ derived graphically at $5,10,15^{\circ} \mathrm{C}, 5$ to $40 \% \mathrm{~S}$, and chromium concentrations of 2 to $128 \mathrm{ppm}$

\begin{tabular}{|c|c|c|c|c|c|c|c|c|c|}
\hline & $5^{\circ} \mathrm{C}$ & 5 & 10 & 15 & 20 & 25 & 30 & 35 & $40 \% \mathrm{~S}$ \\
\hline \multirow{8}{*}{ Chromium conc. } & 2 & 125 & 245 & 350 & 370 & $>384$ & $>384$ & $>384$ & 265 \\
\hline & 4 & 88 & 190 & 270 & 320 & $>384$ & $>384$ & $>384$ & 135 \\
\hline & 8 & 64 & 105 & 220 & 210 & 300 & 370 & 220 & 240 \\
\hline & 16 & 39 & 54 & 105 & 120 & 170 & 210 & 310 & 220 \\
\hline & 32 & 15 & 16.5 & 40 & 58 & 110 & 135 & 115 & 120 \\
\hline & 64 & 5.8 & 14.5 & 22 & 26 & 50 & 80 & 85 & 56 \\
\hline & 128 & 3.2 & 9.5 & 13.5 & 14 & 29 & 48 & 31 & 41 \\
\hline & $10^{\circ} \mathrm{C}$ & 5 & 10 & 15 & 20 & 25 & 30 & 35 & $40 \% \mathrm{~S}$ \\
\hline \multirow{8}{*}{ Chromium conc. } & 2 & 110 & 220 & 220 & $>384$ & $>384$ & 320 & $>384$ & $>384$ \\
\hline & 4 & 68 & 130 & 200 & 220 & 360 & 230 & $>384$ & $>384$ \\
\hline & 8 & 29 & 56 & 120 & 190 & 330 & 180 & 210 & 330 \\
\hline & 16 & 15 & 37 & 100 & 125 & 155 & 128 & 170 & 150 \\
\hline & 32 & 9 & 22 & 52 & 70 & 88 & 96 & 115 & 90 \\
\hline & 64 & 7.5 & 14 & 22 & 46 & 56 & 54 & 85 & 72 \\
\hline & 128 & $\cdot 1$ & 6.5 & 12.5 & 20 & 18.5 & 36 & 29 & 34 \\
\hline & $15^{\circ} \mathrm{C}$ & 5 & 10 & 15 & 20 & 25 & 30 & 35 & $40 \% \mathrm{~S}$ \\
\hline \multirow{7}{*}{ Chromium conc. } & 2 & 44 & 54 & 115 & 195 & 140 & 230 & 145 & 100 \\
\hline & 4 & 33 & 58 & 105 & 133 & 100 & 180 & 130 & 72 \\
\hline & 8 & 24 & 37 & 90 & 76 & 80 & 155 & 105 & 56 \\
\hline & 16 & 11 & 18.5 & 64 & 56 & 60 & 60 & 60 & 50 \\
\hline & 32 & 6.6 & 12.5 & 21 & 30 & 32 & 48 & 28 & 25 \\
\hline & 64 & $\cdot 1$ & 6 & 13.5 & 13.5 & 23 & 27 & 20 & 19.0 \\
\hline & 128 & $\cdot 1$ & $\bullet 1$ & 6.2 & 9 & 12 & 12.5 & 13 & 12.5 \\
\hline
\end{tabular}


chromium concentration at each temperature and salinity combination, and a straight line fitted through the data. The median lethal concentration $\left(\mathrm{LC}_{50}\right)$ for 24 , $48,96,192$ and $384 \mathrm{~h}$ was read from each graph.

\section{STATISTICAL ANALYSIS}

Three-factor analysis of variance of untransformed $\mathrm{LT}_{50}$ values was partitioned into linear and quadratic forms for the main factors (temperature, concentration and salinity) and their second order interactions. Since there were no replicates, the third order interaction was taken as the error term (Davies, 1979). Corophium volutator and Macoma balthica data were analysed separately (see Tables 3 and 6). Terms significant at $\mathrm{p}<0.01$ were included in a response surface model for each species (Nereis diversicolor data could not be analysed in a similar way because the data set for this species was incomplete). Coefficients for the terms were found by multiple regression and the resulting equations used to draw isopleths of $\mathrm{LT}_{50}$. (N.B. $\mathrm{T}=$

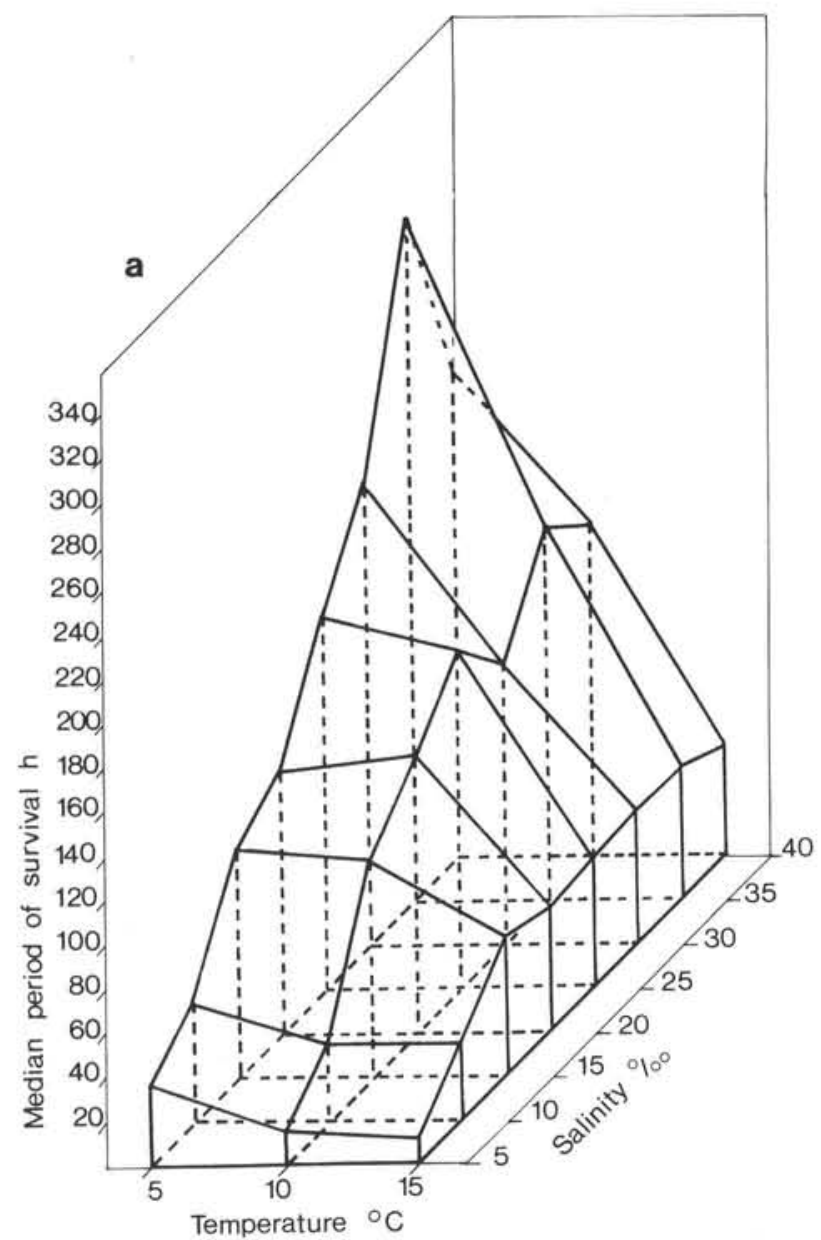

temperature ${ }^{\circ} \mathrm{C}, \mathrm{C}=$ concentration chromium ppm, $\mathrm{S}=$ salinity $\% \mathrm{NaCl}$ ).

Corophium volutator:

$$
\begin{aligned}
\mathrm{LT}_{50} & =172.4-25.5 \mathrm{~T}-7.02 \mathrm{C}+13.24 \mathrm{~S}+0.687 \mathrm{~T}^{2} \\
& +0.0477 \mathrm{C}^{2}-0.2846 \mathrm{~S}^{2}+0.4067 \mathrm{TC}+1.469 \mathrm{TS} \\
& -0.1623 \mathrm{CS}-0.00221 \mathrm{TC}^{2}-0.0867 \mathrm{~T}^{2} \mathrm{~S} \\
& +0.00213 \mathrm{CS}^{2}+0.00000565 \mathrm{C}^{2} \mathrm{~S}^{2} \\
\mathrm{R}^{2} & =82.3 \%
\end{aligned}
$$

Macoma balthica:

$\mathrm{LT}_{50}=237.7-14.45 \mathrm{~T}-1.77 \mathrm{C}+8.56 \mathrm{~S}-0.02 \mathrm{SC}$ $+0.00349 \mathrm{~T}^{2} \mathrm{~S}+0.000475 \mathrm{C}^{2} \mathrm{~S}-0.00000992 \mathrm{C}^{2} \mathrm{~S}^{2}$

$\mathrm{R}^{2}=84.8 \%$.

\section{RESULTS}

\section{Corophium volutator}

$\mathrm{LT}_{50}$ values are shown in Table 1 . The combined effect of temperature and salinity on median period of survival $\left(\mathrm{LT}_{50}\right)$ at 2 chromium levels (16 and $64 \mathrm{ppm}$ ) is demonstrated in Fig. 1a, b. The susceptibility of

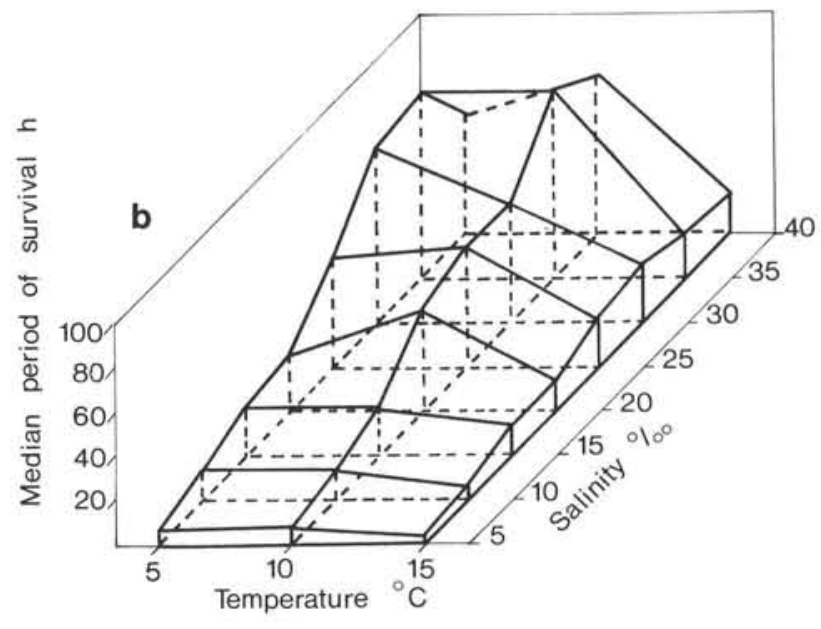

Fig. 1. Corophium volutator. Effect of temperature and salinity on median periods of survival (h) at chromium concentrations of (a) 16 ppm, (b) 64 ppm 
Corophium volutator to chromium depends on both factors, greatest tolerance occurring at low temperature and high salinity, greatest sensitivity occurring at high temperature and low salinity. Comparison of Fig. $1 \mathrm{a}$ with $1 \mathrm{~b}$ shows the higher $\mathrm{LT}_{50}$ values recorded for the lower chromium concentration, though the overall pattern of response was similar at both levels.

$\mathrm{LC}_{50}$ values for Corophium volutator (Table 2) reveal an ameliorating effect of high salinity and low temperature; $192 \mathrm{~h} \mathrm{LC}_{50}$ values are much lower than $96 \mathrm{~h}$ values.

Analysis of variance (Table 3 ) indicates that both linear and quadratic effects of temperature $(\mathrm{T})$, concentration (C) and salinity (S) significantly affect $\mathrm{LT}_{50}$ values. The following interactive terms were all significant $(\mathrm{p}<0.01), \mathrm{T} \times \mathrm{C}, \mathrm{T} \times \mathrm{C}^{2}, \mathrm{~T} \times \mathrm{S}, \mathrm{T}^{2} \times \mathrm{S}, \mathrm{C} \times \mathrm{S}$, $\mathrm{C} \times \mathrm{S}^{2}, \mathrm{C}^{2} \times \mathrm{S}^{2}$. These 2-way significant interactions indicate that the effect of one variable on $\mathrm{LT}_{50}$ is dependent on exposure levels of the other variable.

Fig. 2 shows the surface response isopleths representing the effect of concentration of chromium and salinity on $\mathrm{LT}_{50}$ values for Corophium volutator at $5{ }^{\circ} \mathrm{C}$. The shape of the contours reveals an interactive effect between chromium concentration and salinity on $\mathrm{LT}_{50}$ at low salinities and low chromium levels. As the chromium concentration increases, the effect of salinity is diminished, until at $32 \mathrm{ppm}$, at salinities above $15 \%$, there is virtually no change in $\mathrm{LT}_{50}$ up to $40 \%$. At chromium levels below $8 \mathrm{ppm}$ the shape of the contours indicates that salinity exerts a greater effect than chromium concentration on $\mathrm{LT}_{50}$ at salinities below $15 \%$. As chromium concentration increases, the interactive effect between salinity and chromium diminishes with chromium exerting an increasingly strong influence over a greater part of the salinity range. The shape of the contours was similar for 10 and $15^{\circ} \mathrm{C}$.

The effect of temperature on the interactive effect between chromium and salinity may be clarified by examining the range of conditions over which a median survival period of $150 \mathrm{~h}$ occurs. At $5{ }^{\circ} \mathrm{C}, 50 \%$ of Corophium volutator survived for $150 \mathrm{~h}$ or more over a salinity range of 6 to $40 \%$ and 2 to $32 \mathrm{ppm}$ chromium, at $10{ }^{\circ} \mathrm{C}$ the range is reduced to 11 to $40 \% \mathrm{~S}$ and 2 to $32 \mathrm{ppm}$ chromium, at $15^{\circ} \mathrm{C}$ the range was further reduced to 24 to $31 \% \mathrm{~S}$ and 2 to $3 \mathrm{ppm}$ chromium.

Table 2. Corophium volutator. Median lethal concentrations $\left(\mathrm{LC}_{50}\right)$ of hexavalent chromium (ppm) at $5,10,15^{\circ} \mathrm{C}$, at 5 to $40 \% \mathrm{~S}$

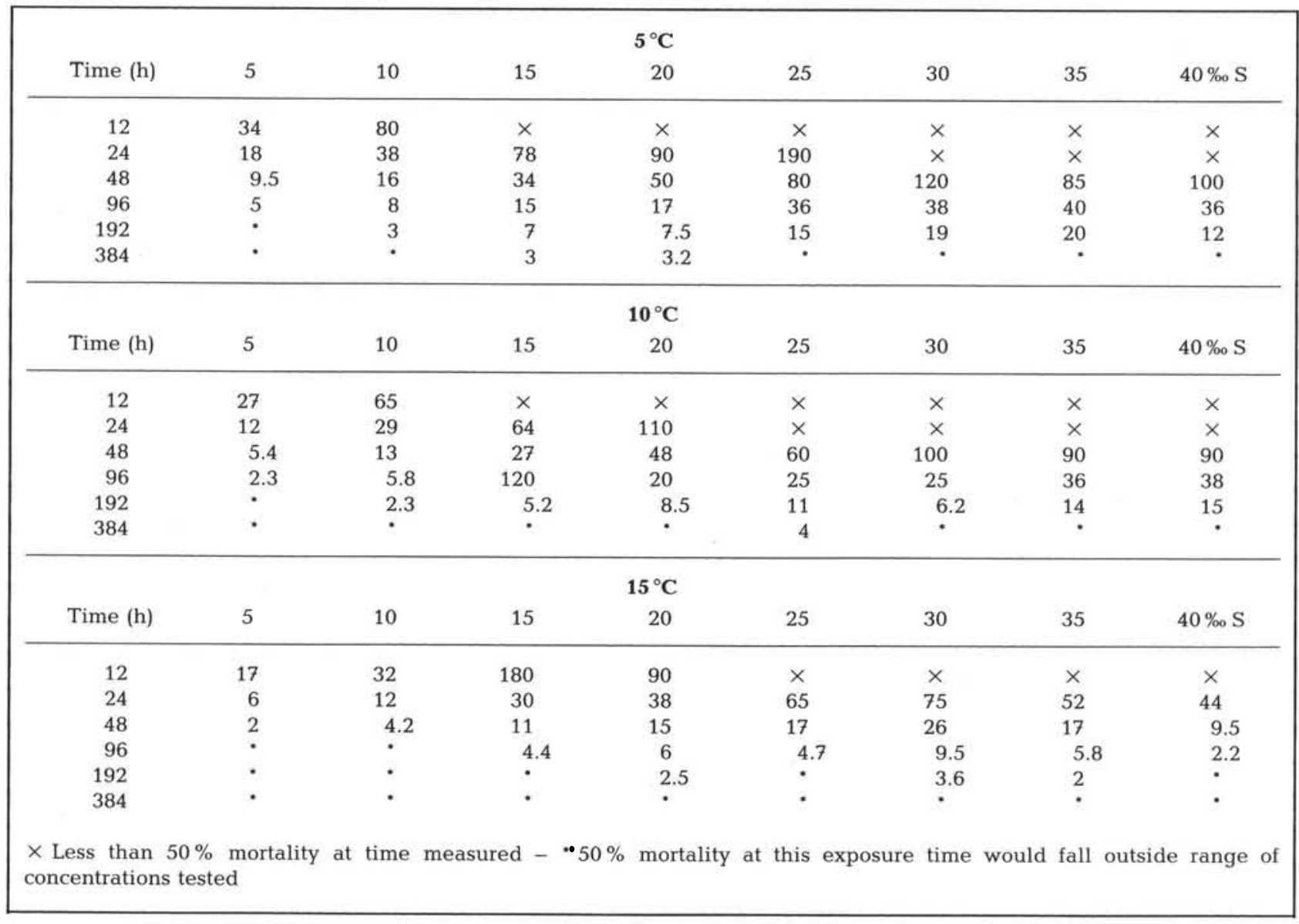


Table 3. Corophium volutator. Analysis of variance of effects of 8 chromium concentrations, 8 salinities and 3 temperatures on median periods of survival. DF: degrees of freedom; MS: mean sum of squares; F: ratio of treatment mean square to error mean square; Lin: linear; Quad: quadratic

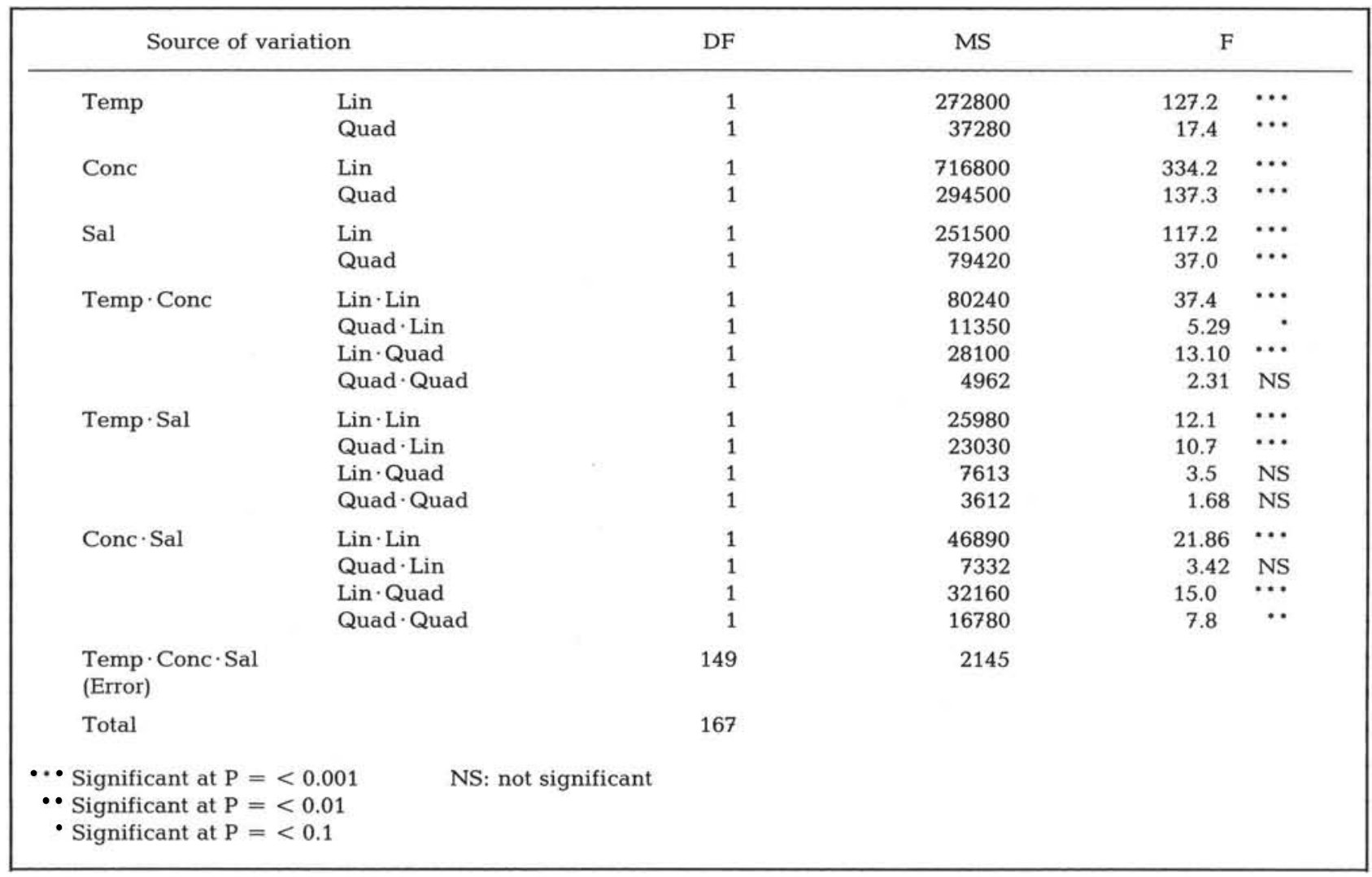

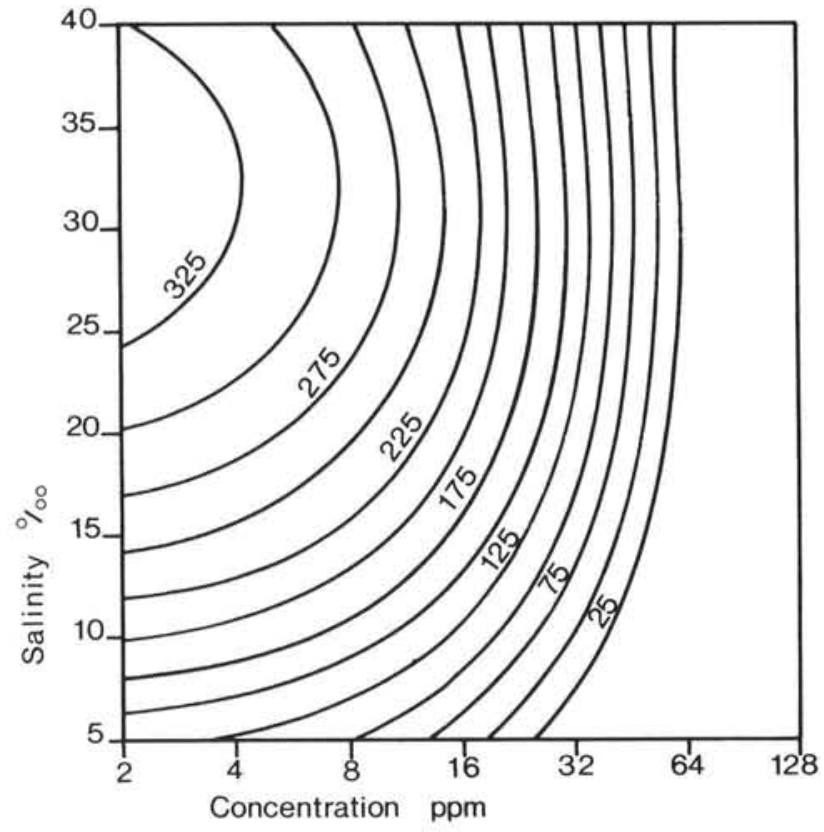

Fig. 2. Corophium volutator. Response surface showing combined effect of chromium concentration and salinity on median period of survival (h) at $5^{\circ} \mathrm{C}$
Fig. 3a and b show response surface isopleths representing the effect of temperature and salinity on $\mathrm{LT}_{50}$ values at chromium levels of 2 and $16 \mathrm{ppm}$, respectively. At the lowest salinity of $5 \%$ an increase in temperature from 5 to $15{ }^{\circ} \mathrm{C}$ results in a 7 -fold decrease in $\mathrm{LT}_{50}$. As salinity is increased to $20 \%$, the temperature effect on $\mathrm{LT}_{50}$ is diminished. The ameliorating effect of salinity lessens at salinities of about $30 \%$, and at salinities of $40 \%$ interacts more strongly with temperature.

Response surface contours are similar in shape at concentrations of $2,4,8$ and $16 \mathrm{ppm}$, with salinity exerting an increasingly strong effect at salinities below $20 \%$ over the whole temperature range. At $32 \mathrm{ppm}$ chromium there is virtually no temperature effect at salinities below $20 \%$, at salinities above $20 \%$ and temperature above $10^{\circ} \mathrm{C}$ there is no temperature effect. At 64 and $128 \mathrm{ppm}$ the prediction of the model is weak.

The effect of chromium concentration on the interactive effect of temperature and salinity is demonstrated by examining the range of conditions over which an $\mathrm{LT}_{50}$ of $150 \mathrm{~h}$ occurs, at $2 \mathrm{ppm} 50 \%$ of 

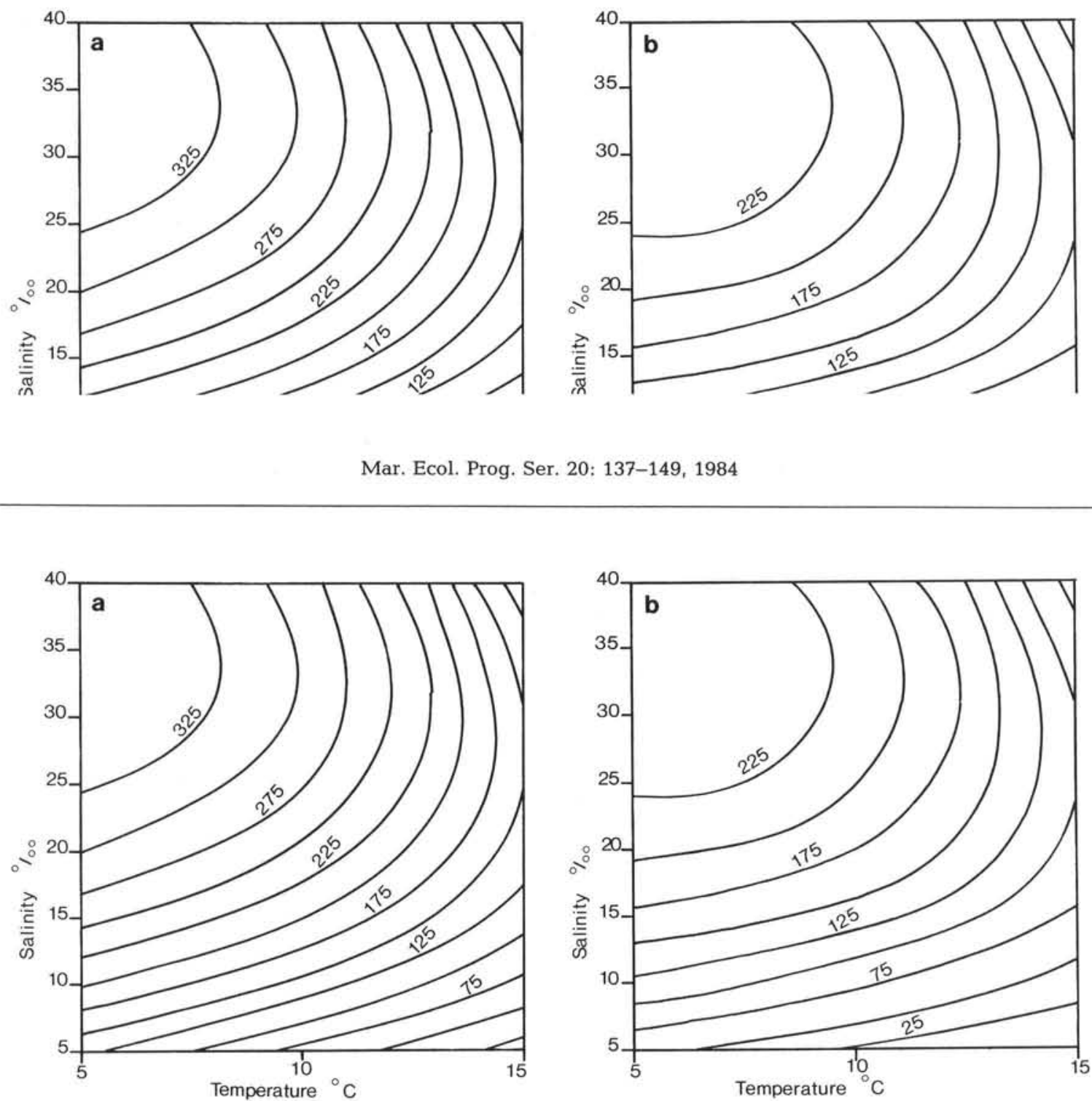

Fig. 3. Corophium volutator. Response surface showing combined effect of temperature and salinity on median period of survival (h) at chromium concentrations of (a) 2 ppm, (b) $16 \mathrm{ppm}$

Corophium volutator would survive over a range of 6 to $40 \% \mathrm{~S}$ from 5 to $15^{\circ} \mathrm{C}$, at $4 \mathrm{ppm}$ the range is 7 to $40 \%$ at 5 to $14{ }^{\circ} \mathrm{C}$, at $32 \mathrm{ppm}$ the range is further reduced to 26 to $40 \%$ at 6 to $10^{\circ} \mathrm{C}$. The range narrows gradually up to $16 \mathrm{ppm}$ with a dramatic contraction at concentrations of $32 \mathrm{ppm}$ and above.

Fig. $4 \mathrm{a}$ and $\mathrm{b}$ are response surface isopleths showing the combined effects of chromium concentration and temperature on $\mathrm{LT}_{50}$ values for Corophium volutator at salinities of 10 and $35 \%$. Maximum LT $_{50}$ values occur at combinations of low temperature and low chromium concentrations at all salinity levels. At low salinity, $10 \%$, temperature does not influence $\mathrm{LT}_{50}$ at

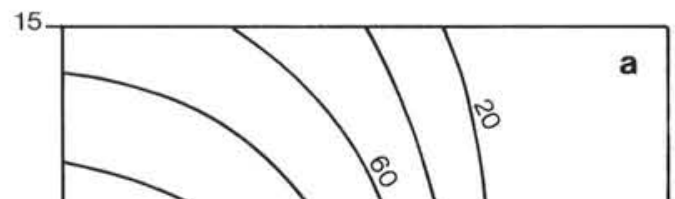

chromium levels above $16 \mathrm{ppm}$, however temperature and chromium concentration interact at levels below $16 \mathrm{ppm}$. As salinity is increased concentration interacts to a greater degree with temperature to affect $\mathrm{LT}_{50}$.

\section{Macoma balthica}

Median periods of survival for Macoma balthica are shown in Table 4. The combined effect of temperature and salinity on $\mathrm{LT}_{50}$ at a low (16 ppm) and a high (64 ppm) chromium level is demonstrated in Fig. 5a and b. Greatest sensitivity to chromium occurs at low

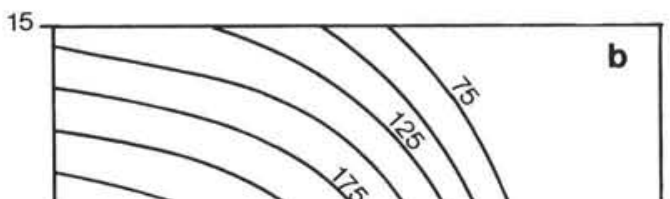


Table 4. Macoma balthica. Median periods of survival (h) $\left(\mathrm{LT}_{50}\right)$ derived graphically at $5,10,15^{\circ} \mathrm{C}, 5$ to $40 \% \mathrm{~S}$, and chromium concentrations of 2 to $512 \mathrm{ppm}$

\begin{tabular}{|c|c|c|c|c|c|c|c|}
\hline \multicolumn{8}{|c|}{$\mathrm{LT}_{50} \mathrm{~h}$} \\
\hline & $5^{\circ} \mathrm{C}$ & 15 & 20 & 25 & 30 & 35 & $40 \%$ S \\
\hline \multirow[t]{10}{*}{ Chromium conc. } & 2 & $>384$ & $>384$ & $>384$ & $>384$ & $>384$ & $>384$ \\
\hline & 4 & $>384$ & $>384$ & $>384$ & $>384$ & $>384$ & $>384$ \\
\hline & 8 & $>384$ & $>384$ & $>384$ & $>384$ & $>384$ & $>384$ \\
\hline & 16 & 280 & $>384$ & $>384$ & $>384$ & $>384$ & $>384$ \\
\hline & 32 & 190 & 280 & $>384$ & $>384$ & $>384$ & $>384$ \\
\hline & 64 & 140 & 185 & 240 & 270 & 320 & 340 \\
\hline & 128 & 130 & 125 & 175 & 195 & 230 & 280 \\
\hline & 256 & 85 & 110 & 120 & 140 & 180 & 210 \\
\hline & 512 & NT & NT & NT & 98 & 90 & 170 \\
\hline & $10^{\circ} \mathrm{C}$ & 15 & 20 & 25 & 30 & 35 & $40 \% \mathrm{~S}$ \\
\hline \multirow[t]{8}{*}{ Chromium conc. } & 2 & $>384$ & $>384$ & $>384$ & $>384$ & $>384$ & $>384$ \\
\hline & 4 & 310 & $>384$ & $>384$ & $>384$ & $>384$ & $>384$ \\
\hline & 8 & 250 & $>384$ & $>384$ & $>384$ & $>384$ & $>384$ \\
\hline & 16 & 190 & 300 & 360 & 360 & $>384$ & $>384$ \\
\hline & 32 & 145 & 210 & 260 & 310 & 310 & $>384$ \\
\hline & 64 & 92 & 160 & 170 & 200 & 360 & $>384$ \\
\hline & 128 & 68 & 68 & 110 & 145 & 145 & 155 \\
\hline & $15^{\circ} \mathrm{C}$ & 15 & 20 & 25 & 30 & 35 & $40 \% \mathrm{~S}$ \\
\hline \multirow[t]{7}{*}{ Chromium conc. } & 2 & 380 & $>384$ & $>384$ & $>384$ & $>384$ & $>384$ \\
\hline & 4 & 200 & $>384$ & $>384$ & $>384$ & $>384$ & $>384$ \\
\hline & 8 & 160 & 250 & $>384$ & $>384$ & $>384$ & $>384$ \\
\hline & 16 & 125 & 195 & 210 & 250 & 320 & $>384$ \\
\hline & 32 & 98 & $\cdot 70$ & 135 & 175 & 185 & $>384$ \\
\hline & 64 & $\cdot 70$ & $\cdot 70$ & 105 & 130 & 130 & $>384$ \\
\hline & 128 & 42 & 58 & 64 & 78 & 78 & 90 \\
\hline
\end{tabular}

salinity and at high temperature. At the highest salinities a temperature effect was not apparent. Table 5 lists $\mathrm{LC}_{50}$ values for $M$. balthica, $192 \mathrm{~h} \mathrm{\textrm {LC } _ { 5 0 }}$ values are lower than $96 \mathrm{~h}$ values.

Table 6 shows the analysis of variance for $\mathrm{LT}_{50}$ data for Macoma balthica. The response surface model is simpler than that derived for Corophium volutator as few of the interactive terms were significant. The linear effects of temperature, concentration and salinity were all highly significant. The following interactive terms were all significant, $\mathrm{T} \times \mathrm{S}_{2}, \mathrm{C} \times \mathrm{S}, \mathrm{C}_{2} \times \mathrm{S}$, $\mathrm{C}^{2} \times \mathrm{S}^{2}$. None of the possible interactions between temperature and concentration was significant and only 1 of the possible 4 interactions between $\mathrm{T} \times \mathrm{S}$ was significant, namely linear temperature $\times$ quadratic salinity.

Table 5. Macoma balthica. Median lethal concentrations $\left(\mathrm{LC}_{50}\right)$ of hexavalent chromium (ppm) at $5,10,15^{\circ} \mathrm{C}$, and 15 to $40 \% \mathrm{~S}$

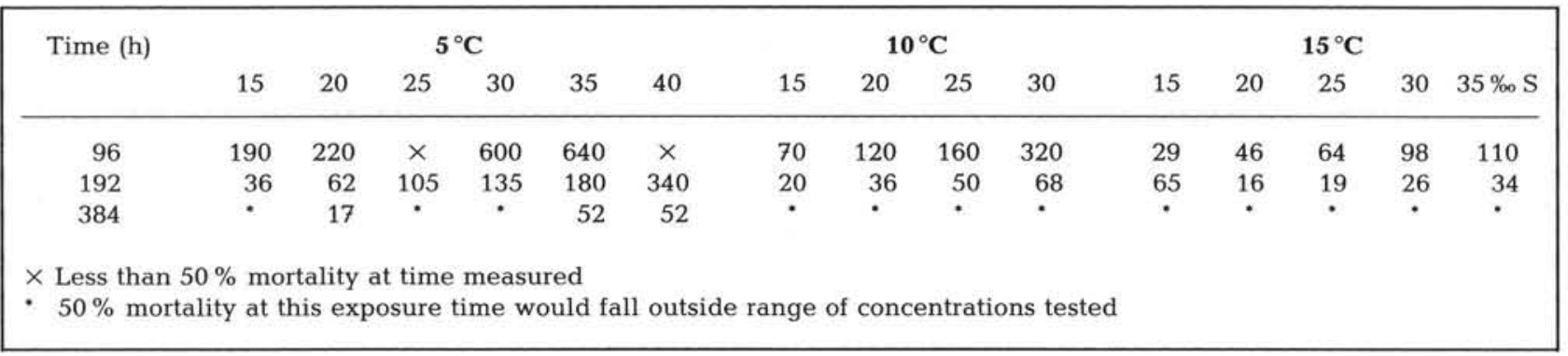



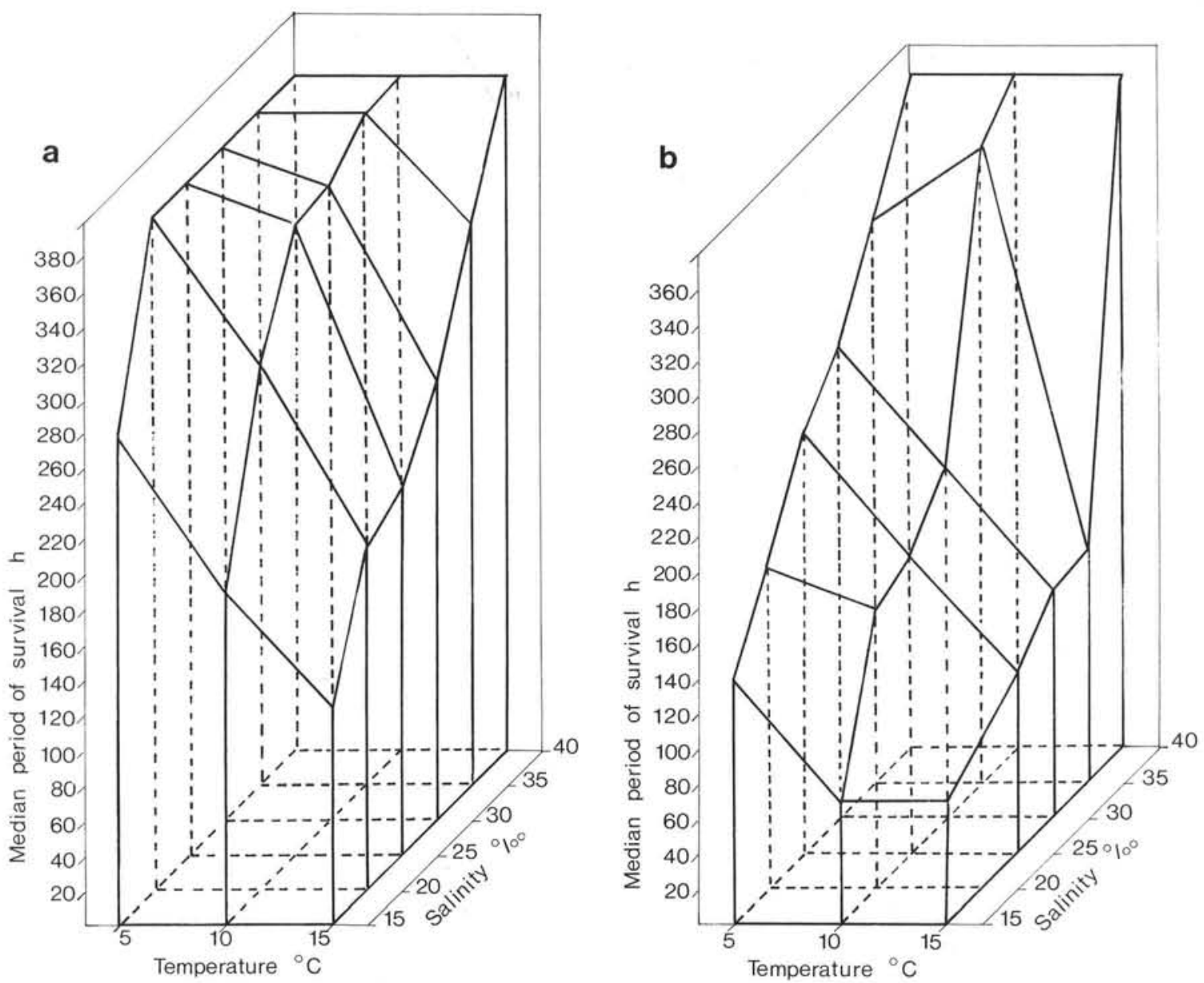

Fig. 5. Macoma balthica. Effect of temperature and salinity on median period of survival (h) at chromium concentrations of (a) 16 ppm, (b) 64 ppm

Fig. 6 illustrates response surface isopleths of the effects of chromium and salinity on $\mathrm{LT}_{50}$ at $10^{\circ} \mathrm{C}$. The shape of the contours shows the interactive effect; $\mathrm{LT}_{50}$ values decrease with decreasing salinity and increasing chromium concentration, maximum values occurring at high salinity and low concentrations. Unlike Corophium volutator, interaction occurs over the whole concentration range, although at salinities above $35 \%$ and concentrations above $64 \mathrm{ppm}$, chromium concentration exerts a stronger effect. Increasing temperature decreases the range over which a certain survival time would be expected, although the pattern of response was the same at all 3 temperatures.

Although analysis of variance indicated a significant interaction between linear temperature and quadratic salinity effects the value of the regression coefficient for this term was small $(b=0.00349)$, so the effect of this interaction on $\mathrm{LT}_{50}$ is small, as indicated by response surface isopleths shown in Fig. 7. Increasing temperature and decreasing salinity acted additively to reduce $\mathrm{LT}_{50}$.

\section{Nereis diversicolor}

$\mathrm{LT}_{50}$ values for Nereis diversicolor at all combinations of temperature, chromium concentration and salinity are shown in Table 7. $\mathrm{LC}_{50}$ values for $N$. diversicolor are listed in Table 8. Detailed analysis of interactions between variables was not possible due to an incomplete data set. This arose as $N$. diversicolor could survive for periods up to $140 \mathrm{~h}$ under certain conditions and $24 \mathrm{~h}$ later all animals were dead, thus preventing graphical estimation of $\mathrm{LT}_{50} . \mathrm{LT}_{50}$ decreased with increasing chromium concentration at all salinity and temperature combinations. The combined effect of temperature and salinity on $\mathrm{LT}_{50}$ of $N$. diversicolor at 2 chromium levels is demonstrated in Fig. 8a and $\mathrm{b}$.

As with Corophium volutator and Macoma balthica maximum tolerance to chromium occurs at high salinity and low temperature. Salinity has a slight effect on $\mathrm{LT}_{50}$, this is least obvious at the highest temperature. Temperature has a greater effect on $\mathrm{LT}_{50}$, greater changes occurring between 5 and $10{ }^{\circ} \mathrm{C}$ than between 10 and $15^{\circ} \mathrm{C}$. 
Table 6. Macoma balthica. Analysis of variance of effects of 8 chromium concentrations, 6 salinities and 3 temperatures on median periods of survival. DF: degrees of freedom; SS: sum of squares; MS: mean sum of squares; F: ratio of treatment mean square to error mean square; Lin: linear; Quad: quadratic

\begin{tabular}{|c|c|c|c|c|}
\hline \multicolumn{2}{|c|}{ Source of variation } & \multirow{2}{*}{$\begin{array}{c}\text { DF } \\
1\end{array}$} & \multirow{2}{*}{$\begin{array}{c}\text { MS } \\
188300\end{array}$} & \multirow{2}{*}{$\begin{array}{c}F \\
\cdots\end{array}$} \\
\hline Temp & $\begin{array}{l}\text { Lin } \\
\text { Quad }\end{array}$ & & & \\
\hline Conc & $\begin{array}{l}\text { Lin } \\
\text { Quad }\end{array}$ & $\begin{array}{l}1 \\
1\end{array}$ & $\begin{array}{r}342100 \\
8614\end{array}$ & $\ddot{*}$ \\
\hline Sal & $\begin{array}{l}\text { Lin } \\
\text { Quad }\end{array}$ & $\begin{array}{l}1 \\
1\end{array}$ & $\begin{array}{r}285800 \\
8229\end{array}$ & $\ddot{*}$ \\
\hline Temp $\cdot$ Conc & $\begin{array}{l}\text { Lin·Lin } \\
\text { Quad·Lin } \\
\text { Lin·Quad } \\
\text { Quad·Quad }\end{array}$ & $\begin{array}{l}1 \\
1 \\
1 \\
1\end{array}$ & $\begin{array}{c}498 \\
2719 \\
318.6 \\
1099\end{array}$ & $\begin{array}{l}\text { NS } \\
\text { NS } \\
\text { NS } \\
\text { NS }\end{array}$ \\
\hline Temp $\cdot$ Sal & $\begin{array}{l}\text { Lin·Lin } \\
\text { Quad·Lin } \\
\text { Lin·Quad } \\
\text { Quad·Quad }\end{array}$ & $\begin{array}{l}1 \\
1 \\
1 \\
1\end{array}$ & $\begin{array}{c}2981 \\
828.8 \\
18300 \\
2083\end{array}$ & $\begin{array}{l}\text { NS } \\
\text { NS } \\
\ddot{N S} \\
\text { NS }\end{array}$ \\
\hline Conc $\cdot$ Sal & $\begin{array}{l}\text { Lin. Lin } \\
\text { Quad·Lin } \\
\text { Lin· Quad } \\
\text { Quad·Quad }\end{array}$ & $\begin{array}{l}1 \\
1 \\
1 \\
1\end{array}$ & $\begin{array}{r}8988 \\
198250 \\
1757 \\
9671\end{array}$ & $\begin{array}{l}\cdots \\
\cdots \\
\text { NS } \\
\cdots\end{array}$ \\
\hline $\begin{array}{l}\text { Temp } \text { Conc } \\
\text { (Error) }\end{array}$ & & 53 & 1248 & \\
\hline $\begin{array}{l}\text { Total } \\
\text { ‥ Significant at } \\
\text { * Significant at } \\
\text { - Significant at }\end{array}$ & $\begin{array}{l}001 \\
01 \\
1\end{array}$ & 71 & & \\
\hline
\end{tabular}

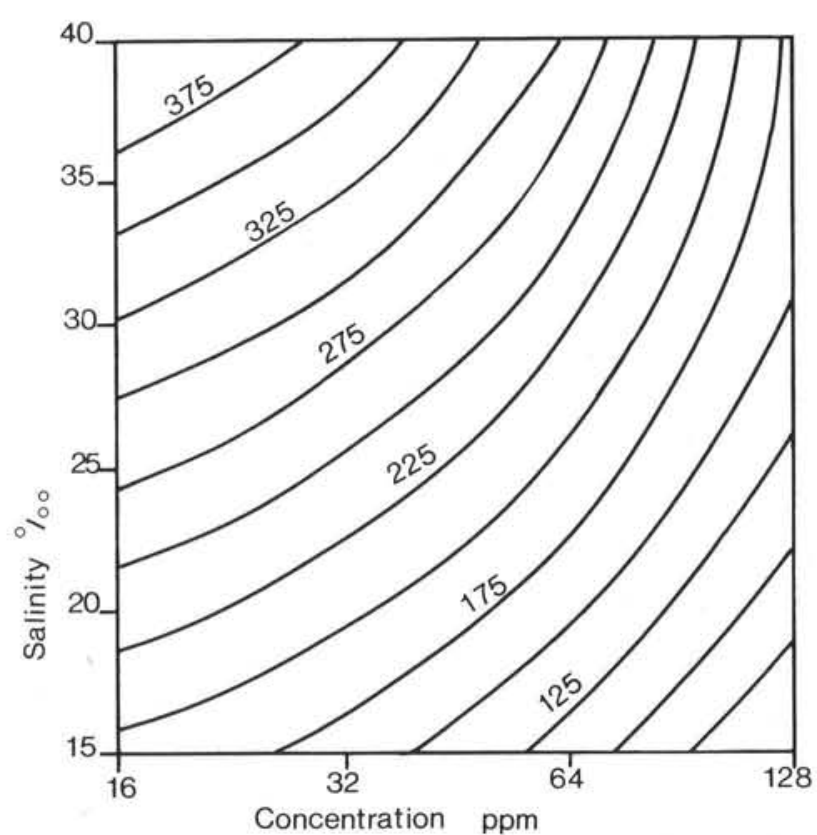

Fig. 6. Macoma balthica. Response surface showing combined effect of chromium concentration and salinity on median period of survival (h) at $10^{\circ} \mathrm{C}$

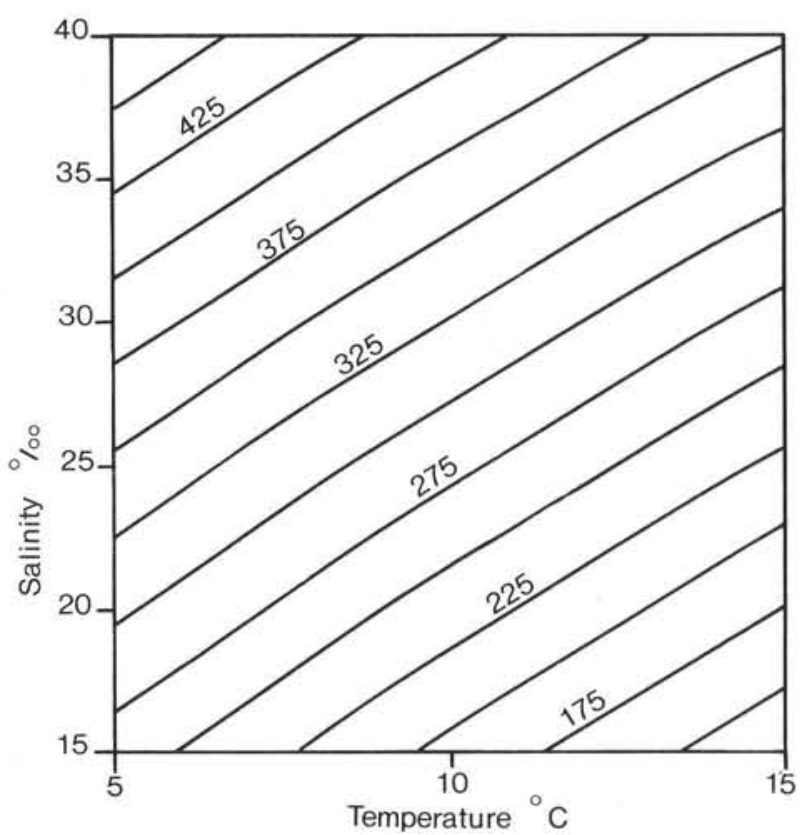

Fig. 7. Macoma balthica. Response surface showing combined effect of temperature and salinity on median period of survival (h) at a chromium concentration of $16 \mathrm{ppm}$ 
Table 7. Nereis diversicolor. Median periods of survival (h) ( $\left.\mathrm{LT}_{50}\right)$ derived graphically at $5,10,15^{\circ} \mathrm{C}, 5$ to $40 \% \mathrm{~S}$, and at chromium concentrations of 0.5 to $64 \mathrm{ppm}$

\begin{tabular}{|c|c|c|c|c|c|c|c|c|c|}
\hline \multicolumn{10}{|c|}{$\mathrm{LT}_{50} \mathrm{~h}$} \\
\hline & $5^{\circ} \mathrm{C}$ & 5 & 10 & 15 & 20 & 25 & 30 & 35 & $40 \% \mathrm{~S}$ \\
\hline \multirow{9}{*}{ Chromium conc. } & 0.5 & $>384$ & $>384$ & $>384$ & $>384$ & $>384$ & $>384$ & $>384$ & $>384$ \\
\hline & 1 & $>384$ & $>384$ & $>384$ & 375 & $>384$ & $>384$ & $>384$ & $>384$ \\
\hline & 2 & $>384$ & $>384$ & 360 & 330 & $>384$ & $>384$ & $>384$ & $>384$ \\
\hline & 4 & 360 & 320 & 305 & 275 & 300 & 340 & $>384$ & $>384$ \\
\hline & 8 & 330 & 300 & 255 & 240 & 250 & 280 & 300 & $>384$ \\
\hline & 16 & 210 & 220 & 215 & 205 & 220 & 210 & 230 & 250 \\
\hline & 32 & 120 & 155 & 170 & 170 & 180 & 190 & 190 & 155 \\
\hline & 64 & 62 & 95 & 120 & 125 & 160 & 150 & 125 & 140 \\
\hline & $10^{\circ} \mathrm{C}$ & 5 & 10 & 15 & 20 & 25 & 30 & 35 & $40 \%$ S \\
\hline \multirow{9}{*}{ Chromium conc. } & 0.5 & $>384$ & 390 & $>384$ & $>384$ & $>384$ & $>384$ & $>384$ & $>384$ \\
\hline & 1 & 280 & 320 & 310 & 300 & $>384$ & 230 & $>384$ & $>384$ \\
\hline & 2 & 190 & 240 & 240 & $\cdot$ & 260 & 270 & 310 & $>384$ \\
\hline & 4 & 160 & 155 & $\cdot$ & 210 & - & . & 250 & 300 \\
\hline & 8 & 130 & 132 & • & . & $\cdot$ & • & 190 & 210 \\
\hline & 16 & 105 & 94 & 105 & 180 & • & • & 145 & 175 \\
\hline & 32 & 85 & $\cdot$ & 95 & 8 & 115 & 105 & 105 & 110 \\
\hline & 64 & 56 & 60 & 76 & 62 & 84 & 80 & 96 & 60 \\
\hline & $15^{\circ} \mathrm{C}$ & 5 & 10 & 15 & 20 & 25 & 30 & 35 & $40 \% \mathrm{~S}$ \\
\hline \multirow{8}{*}{ Chromium conc. } & 0.5 & $>384$ & $>384$ & 300 & 330 & 370 & 220 & 320 & $>384$ \\
\hline & 1 & 180 & 190 & 200 & - & 240 & 190 & 210 & 360 \\
\hline & 2 & 150 & 150 & 170 & 200 & 190 & 120 & 140 & 290 \\
\hline & 4 & 120 & • & 100 & 130 & 105 & 90 & 120 & 115 \\
\hline & 8 & 100 & 98 & 90 & . & 78 & . & 110 & 95 \\
\hline & 16 & 78 & 80 & 85 & 85 & . & • & 100 & 76 \\
\hline & 32 & . & 70 & 74 & $\cdot$ & • & $\cdot$ & 72 & 72 \\
\hline & 64 & $\cdot$ & 52 & • & 62 & 68 & $\cdot$ & • & • \\
\hline
\end{tabular}

Table 8. Nereis diversicolor. Median lethal concentration $\left(\mathrm{LC}_{50}\right)$ of hexavalent chromium (ppm) at $5,10,15^{\circ} \mathrm{C}$, and 5 to $40 \% \mathrm{~S}$

\begin{tabular}{|c|c|c|c|c|c|c|c|c|c|c|c|c|c|c|c|c|c|c|c|c|c|c|c|c|}
\hline \multirow[t]{2}{*}{ Time (h) } & \multicolumn{8}{|c|}{$5^{\circ} \mathrm{C}$} & \multicolumn{8}{|c|}{$10^{\circ} \mathrm{C}$} & \multicolumn{8}{|c|}{$15^{\circ} \mathrm{C}$} \\
\hline & 5 & 10 & 15 & 20 & 25 & 30 & 35 & 40 & 5 & 10 & 15 & 20 & 25 & 30 & 35 & 40 & 5 & 10 & 15 & 20 & 25 & 30 & 35 & $40 \% \mathrm{~S}$ \\
\hline 96 & 56 & 80 & $\times$ & $\times$ & $\times$ & $\times$ & $\times$ & $\times$ & 19 & 22 & 27 & 65 & 55 & 34 & 52 & 40 & 7.5 & 9.5 & 8.5 & 12 & 12 & 7.5 & 22 & 16 \\
\hline 192 & 15 & 18 & 19 & 17 & 26 & 26 & 27 & 26 & 2.9 & 3.5 & 4 & 5.4 & 5.8 & 4 & 8 & 12 & $\cdot$ & 1 & 1.5 & 2 & 2 & 1.5 & 3.3 & 5.2 \\
\hline 384 & 3.8 & 4.4 & $\cdot$ & $\cdot$ & $\cdot$ & $\cdot$ & $\cdot$ & $\cdot$ & $\cdot$ & .7 & $\cdot$ & $\cdot$ & $\cdot$ & $\cdot$ & $\cdot$ & $\cdot$ & $\cdot$ & $\cdot$ & $\cdot$ & $\cdot$ & $\cdot$ & $\cdot$ & • & $\cdot$ \\
\hline
\end{tabular}

\section{DISCUSSION}

The results have clearly documented significant effects of temperature, salinity and chromium concentration on the acute toxicity of chromium to Corophium volutator and Macoma balthica. In general, toxicity increased with increased temperature and increased chromium concentration and decreased with an increase in salinity. However, in C. volutator there was a decrease in toxicity with an increase in salinity over the range 5 to $30 \%$, with evidence of further salinity increase up to $40 \%$ causing increased toxicity.

Temperature, salinity and chromium concentration interacted in a complex way to affect median survival 

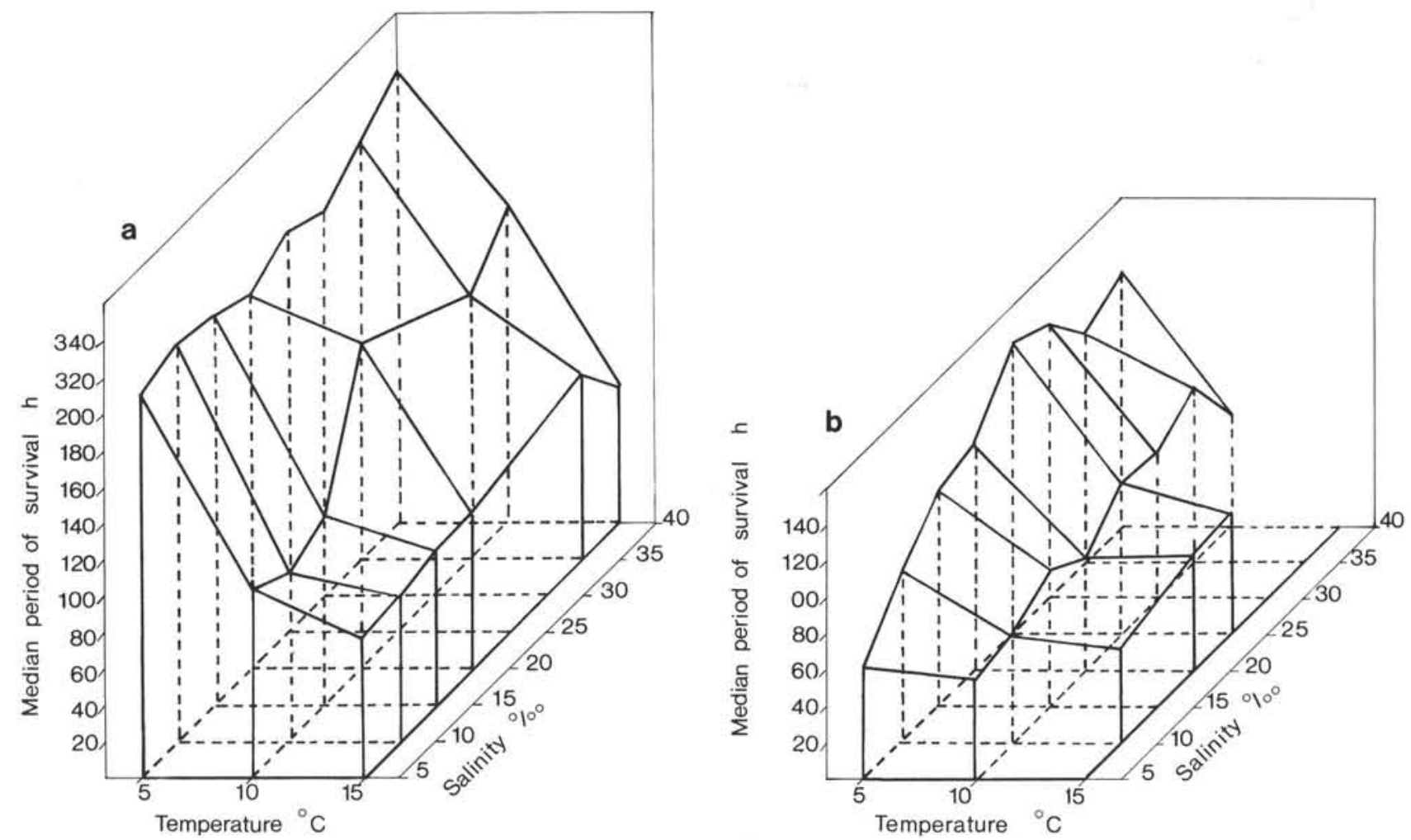

Fig. 8. Nereis diversicolor. Effect of temperature and salinity on median period of survival (h) at chromium concentrations of (a) 16 ppm, (b) 64 ppm

times of Corophium volutator. The combined interactions of chromium concentration $\times$ salinity, temperature $\times$ salinity and chromium concentration $\times$ temperature all significantly decreased $\mathrm{LT}_{50}$ values. However the effect of chromium on $C$. volutator at concentrations above $64 \mathrm{ppm}$ is so great that these interactive effects are only significant at lower concentrations.

In contrast, the interactive effect of these variables has less influence on the median survival times of Macoma balthica. Only the interactive effect of salinity and increasing chromium concentration significantly decreased $\mathrm{LT}_{50}$.

The percentage variance accounted for by the multiple regression analysis was $82.3 \%$ for Corophium volutator and $84.8 \%$ for Macoma balthica, illustrating that the experimental models provide a reasonable fit for the test results and that they each represent a good predictive model of the effect of salinity, temperature and chromium concentration on median survival periods.

In Nereis diversicolor, an increase in toxicity occurred with increased temperature, however the effect of salinity was less marked than in the other two species.

All experiments documented a progressive increase in toxicity values $\left(\mathrm{as} \mathrm{LC}_{50}\right)$ with time. The 'log concentration-log response' curves for all species revealed a straight line relation. Lloyd (1979) and Franklin (1980) state that a linear concentration/response relation indicates that the test organism has no method of detoxification for this pollutant, and that there is no lethal threshold concentration (or asymptote), so that prolonged exposure to concentrations below that of the $96 \mathrm{~h} \mathrm{LC}_{50}$ will be lethal. In the present study this effect of time was clearly seen in Corophium volutator with progressive increase in toxicity with time, at up to $384 \mathrm{~h}$. The other species under most conditions showed a similar response. The effect of chromium on these 3 species may be compared with their known ecological and physiological tolerances. All 3 species are well adapted to life in estuaries, and show considerable euryhalinity. C. volutator and Nereis diversicolor are classified as 'true estuarine species', whereas Macoma balthica is classified as 'euryhaline marine species' (McLusky, 1971). This distinction is made on the basis of their physiology and ecology. M. balthica, although it occurs widely in estuaries, exhibits no osmoregulation and its tissue remains iso-osmotic with the medium in all salinities; consequently it is unable to live in estuaries below 10 to $12 \%$. It can tolerate lower salinities for brief periods by closing its shells, but cannot endure prolonged periods of low salinities. This fact was also seen in the present study, as control animals died at 5 and $10 \%$, and consequently no toxicity studies were possible at these salinities. An 
increase in salinity above $15 \%$ caused a progressive decrease in toxicity, up to 35 to $40 \%$, a response pattern which may be typical of a euryhaline marine animal.

Corophium volutator and Nereis diversicolor are both regarded as 'true estuarine' species. Both are able to osmoregulate when kept in low salinities (McLusky, 1968; Oglesby, 1969). C. volutator can tolerate salinities from 2 to $50 \%$, but only grows and reproduces between 5 and $15 \%$. Salinity experiments reveal a preference for the 10 to $30 \%$ range, with the 'optimal' salinity at $20 \%$ (McLusky, 1970). The present study has shown a decrease in toxicity with increased salinity up to $30 \%$, with evidence of increased toxicity beyond that point.

Nereis diversicolor is the most typical annelid of British estuaries, living down to salinities of $1 \%$. Above about $20 \%$ it is replaced by $N$. virens, $N$. pelagica or Nephtys hombergi (McLusky, 1971). In the laboratory it is well able to live in salinities above $20 \%$, so its relative scarcity from higher salinities may be attributable to ecological competition rather than to physiological intolerance. It can osmoregulate well and, like Corophium volutator, maintains its blood hyper-osmotic to the medium in low salinities. Whereas chromium toxicity in Macoma balthica and $C$. volutator was markedly affected by salinity, this effect is not obvious in $N$. diversicolor. There is however still an effect, and the salinity at which minimal toxicity occurs $(20$ to $30 \%$ ) is, like C. volutator, higher than the normal ecological salinity of the animal.

The toxicity effects observed in the present study may be compared with the only other studies known of the effect of chromium on estuarine invertebrates. Frank and Robertson (1979) reported on the effect of chromium on juvenile blue crabs Callinectes sapidus at 3 salinities, and one temperature and, as in the present study, found that toxicity decreased with increasing salinity $\left(48 \mathrm{~h} \mathrm{LC}_{50} \mathrm{~s}: 34 \mathrm{ppm}\right.$ chromium at $1 \%$ to $98 \mathrm{ppm}$ chromium at $35 \%$ ). Eisler and Hennekey (1977) compared the toxicity of several heavy metals to many species of estuarine invertebrates, at one temperature and salinity, and found the rank order of toxicity to be: $\mathrm{Hg}^{2+} \gg \mathrm{Cd}^{2+}>\mathrm{Zn}^{2+}>\mathrm{Cr}^{6+} \gg \mathrm{Ni}^{2+}$, with annelida more sensitive to chromium than other phyla, which is in agreement with the studies of Oshida (1976, 1977), and Oshida et al. (1981) on the sublethal effects of chromium. Thus in both the literature and the present study, the taxonomic ranking of toxicity is generally annelida $>$ crustacean $>$ mollusc. In the present study, however, the order was Corophium, Nereis, Macoma under some conditions of temperature and salinity, and Nereis, Corophium, Macoma under other conditions. The bivalve mollusc Macoma balthica was always the most tolerant species.
The range of toxicity values for a single estuarine species exposed to different salinity and temperature combinations in the present study (Nereis diversicolor 0.7 to $80 \mathrm{ppm}$; Corophium volutator 3 to $120 \mathrm{ppm}$; Macoma balthica 6 to $640 \mathrm{ppm}$, all as the $\mathrm{LC}_{50}$ over periods of 12 to $384 \mathrm{~h}$ ), exceeds the total range of toxicity values reported in literature for all species in marine and fresh-water conditions (2 to $100 \mathrm{ppm}$ ) as reported by Taylor (1981) and Mance et al. (1984). The fact that the range of toxicity values for a single species under different environmental conditions can exceed the reported range for several species emphasizes that single values for the toxicity of chromium, or other metals, should be treated with extreme caution. It should be emphasized that these values are lethal toxicity values, and should not be confused with sublethal values, for example a value of $1.26 \mathrm{ppm}$ maximum proposed by Oshida et al. (1981), which are based on the effects of chromium on the reproduction of annelids.

When an effluent containing chromium is being licensed, the present results emphasize the need for the controlling authority to determine the acute toxicity under conditions that approximate to the field discharge conditions, rather than relying on values from literature which are invariably derived under different environmental conditions. Similarly the results emphasize the need to consider the range of environmental conditions at the point of discharge, and to base toxicity studies on the 'worst' combination of environmental conditions that can possibly occur.

Acknowledgments. This study has been supported financially by the Water Research Centre, Stevenage. We thank expecially Dr. G. Mance of WRC for advice and support.

\section{LITERATURE CITED}

Anonymous SCA Biological Methods (1980). Working Group 7.4. Acute toxicity tests in seawater. TTP 31 (Revise IV), $33 \mathrm{pp}$

Coglianese, M. P. (1982). The effects of salinity on copper and silver toxicity to embryos of the Pacific oyster. Archs. environ. Contam. Toxicol. 11: 297-303

Cotter, A. J. R., Phillips, D. J. H., Ahsanullah, M. (1982). the significance of temperature, salinity and zinc as lethal factors for the mussel Mytilus edulis in a polluted estuary. Mar. Biol. 68: 135-141

Davies, O. L. (1979). The design and analysis of industrial experiments. Longman, New York

Denton, G. R. W., Burdon-Jones, C. (1982). The influence of temperature and salinity upon the acute toxicity of heavy metals to the banana prawn (Penaeus merguiensis). Chem. Ecol. 1: 131-143

Eisler, R., Hennekey, R. J. (1977). Acute toxicities of $\mathrm{Cd}^{2+}$, $\mathrm{Cr}^{6+}, \mathrm{Hg}^{2+}, \mathrm{Ni}^{2+}$ and $\mathrm{Zn}^{2+}$ to estuarine macrofauna. Archs. environ. Contam. Toxicol. 6: 315-323 
Frank, P. M., Robertson, P. B. (1979). The influence of salinity on toxicity of cadmium and chromium to the blue crab, Callinectes sapidus. Bull. environm. Contam. Toxicol. 21: 74-78

Franklin, F. L. (1980). Assessing the toxicity of industrial wastes, with particular reference to variations in sensitivity of test animals. MAFF Fisheries Research Technical Report No. 61, $10 \mathrm{pp}$

Frey, B. E., Reidel, G. F., Bass, A. E., Small, L. F. (1983). Sensitivity of estuarine phytoplankton to hexavalent chromium. Estuar. coast Shelf. Sci. 17: 181-187

Khayrallah, N., Jones, A. M. (1975). A survey of the benthos of the Tay estuary. Proc. R. Soc., Edinb. (B) 75: 113-135

Lloyd, R. (1979). Toxicity tests with aquatic organisms. Lecture presented at the Sixth FAO/SIDA Workshop of Aquatic Pollution in relation to protection of living resources. Tome, FAO, TF-RAD 112 (SWE) (- Suppl.1): 165-178

Mance, G., Brown, V. M., Gardiner, J., Yates, S. J. (1984). Proposed enivironmental quality standards for List 2 substances in water; Chromium. Technical Report No. 207. Water Research Centre, Medmenham

McLusky, D. S. (1968). Aspects of osmotic and ionic regulation in Corophium volutator. J. mar. biol. Ass. U. K. 48: 769-781
McLusky, D. S. (1970). Salinity preference in Corophium volutator. J. mar. Biol. Ass. U. K. 50: 747-752

McLusky, D. S. (1971). Ecology of estuaries. Heinemann, London

Oglesby, L. C. (1969). Salinity stress and desiccation in intertidal worms. Am. Zool. 9: 319-331

Oshida, P. S. (1976). Effects of chromium on reproduction in polychaetes. Southern California Coastal Water Research Project, El Segundo, California, Annual Report, p. 161-167

Oshida, P. S. (1977). A safe level of hexavalent chromium for a marine polychaete. Southern California Coastal Water Research Project, El Segundo, California, Annual Report, p. $169-180$

Oshida, P. A., Word, L. S., Mearns, A. J. (1981). Effects of hexavalent and trivalent chromium on the reproduction of Neanthes arenaceodentata (Polychaeta). Mar. environ. Res. 5: 41-49

Taylor, D. (1981). A summary of the data on the toxicity of various metals to aquatic life II. Chromium. ICI Brixham Report 2127: 1-27

Theede, H. (1980) Physiological responses of estuarine animals to cadmium pollution. Helgoländer Meeresunters. 33: $26-35$ 